\title{
Gender trends in authorship of Pediatric Radiology publications and impact of the COVID-19 pandemic
}

\author{
Rama S. Ayyala ${ }^{1,2} \cdot$ Andrew T. Trout ${ }^{1,2,3}$
}

Received: 16 June 2021 / Revised: 20 August 2021 / Accepted: 20 September 2021 / Published online: 21 October 2021

(c) The Author(s), under exclusive licence to Springer-Verlag GmbH Germany, part of Springer Nature 2021

\begin{abstract}
Background The coronavirus disease 2019 (COVID-19) pandemic has heightened existing gender differences in academic productivity in medicine. There have been discrepant repercussions for women in academics due to the pandemic, including fewer publications, potentially impacting academic advancement.

Objective To evaluate trends over time in the gender of authors of manuscripts submitted to Pediatric Radiology.

Materials and methods This retrospective review of unsolicited manuscripts submitted to Pediatric Radiology from January 2017 to December 2020 included only submissions from North America. For each submission, genders of the first, last (senior) and corresponding authors were inferred by inspection or confirmed by internet search. Chi-square and Fisher exact tests were used to compare authorship gender proportions. Quarterly comparisons between 2019 and 2020 were performed to assess for differences during the COVID-19 pandemic.

Results Between 2017 and 2020, 1,018 manuscripts were submitted. There was no significant difference in female authorship over time ( $P>0.05$ for first, last and corresponding authors), but there was an increase in female first authorship (38.6\% in $2017,43.2 \%$ in 2020). The frequencies of female first $(P=0.03)$ and last $(P=0.01)$ authors were significantly higher for educational manuscripts (reviews and pictorial essays) versus other manuscript types. Manuscript submissions increased in the second quarter of 2020; however, there was a statistically significant decrease in last authorship by women during this period $(P=0.02)$.

Conclusion Female authorship of manuscripts submitted to Pediatric Radiology has remained relatively stable between 2017 and 2020. During the early phase (March-May 2020) of the COVID-19 pandemic, female last authorship was significantly lower versus the previous year.
\end{abstract}

Keywords Authorship · COVID-19 · Gender $\cdot$ Pediatric radiology $\cdot$ Publications

\section{Introduction}

In early 2020, the onset of the coronavirus disease 2019 (COVID-19) pandemic led to various recommended and mandated social distancing protocols, which impacted normal daily routines. In radiology, this led to changes in

Rama S. Ayyala

rama.ayyala@cchmc.org

1 Department of Radiology,

Cincinnati Children's Hospital Medical Center,

3333 Burnett Ave., OH 45229 Cincinnati, USA

2 Department of Radiology, University of Cincinnati College of Medicine, Cincinnati, OH, USA

3 Department of Pediatrics, Cincinnati Children's Hospital Medical Center, Cincinnati, OH, USA clinical staffing to accommodate appropriate social distancing and safety for both staff and patients. At many centers, these changes included increased remote working capabilities, which needed to be juggled with new non-work-related responsibilities that developed simultaneously. These new onset responsibilities, such as interrupted childcare, overseeing distance learning for students, and protecting high-risk and vulnerable family members from the virus, disproportionately affected women, who are more likely to be primary caregivers [1].

This phenomenon of managing both household and childcare duties as well as work responsibilities is not new during the COVID-19 pandemic and has been encompassed in the terms "double burden" or "second shift" [2-4]. In broad terms, women do 2.6 times the amount of domestic work compared to men, as demonstrated by the United Nations 
in 2018 [5]. Female physicians are subject to the "double burden," with female pediatricians reporting having greater responsibility for dependents than male counterparts, and hiring more help for cleaning, outside work and childcare [6]. This long-established "double burden" has been exacerbated by the COVID-19 pandemic, with women having to bear a greater share of now increased responsibilities at home. This exacerbation is thought to partly contribute to negative impacts on academic careers and advancement for women in medicine [7, 8].

Before the COVID-19 pandemic, a gender gap in academic advancement in radiology had been established. A 2018 study of 5,089 academic radiologists in the United States showed fewer female full professors than males (16.5\% vs. $26.1 \%$ ), fewer total first and last female author publications than male author publications, and women being less likely to have National Institutes of Health (NIH) funding [9]. Since the onset of COVID-19, these trends may have been exacerbated. Two studies evaluating trends of gender differences in publications among radiology journals have shown an overall decrease in female first author and last author publications during the early phases of the COVID-19 pandemic in comparison to respective time periods in previous years $[10,11]$. The overall proportion of women practicing in radiology has been stable at $25 \%$ since 2012 [12]; however, pediatric radiology is one of few radiology subspecialties with more equal female and male representation [13]. Given this representation of women in pediatric radiology, broadly understanding gender representation in academic publishing in the field, and specifically understanding the impact of the COVID-19 pandemic on the publishing productivity of women, is crucial to continue to move toward gender equity in academic pediatric radiology. The purpose of this manuscript is to evaluate trends over time in the gender of authors of manuscripts submitted to Pediatric Radiology, the academic journal for the Society for Pediatric Radiology (SPR). Our hypothesis was that female authorship was lower during the COVID-19 pandemic in comparison to previous years.

\section{Materials and methods}

Approval from the institutional review board, with a waiver of documentation of informed consent, was obtained for this retrospective review of manuscripts submitted to Pediatric Radiology.

\section{Authorship and manuscript data}

The manuscript database for Pediatric Radiology (Editorial Manager; Aries Systems Corporation, North Andover, MA) was accessed by journal staff to obtain information regarding manuscripts submitted from January 2017 through December 2020. For the purpose of the current study, only unsolicited manuscripts were included (original articles, case reports, reviews and pictorial essays). Solicited manuscripts, including those in special issues, and other manuscript types were excluded (commentaries, editorials, book reviews, historical perspectives, letters to the editor and replies, minisymposia and society pages).

Only manuscripts from North America (the United States, Mexico and Canada) were included. This was based on the difficulty consistently verifying the gender of authors of papers originating outside North America based on inference and internet searches.

For each manuscript submission that met inclusion criteria, the following was recorded: date of submission, manuscript title, manuscript type, all author names, institution of the corresponding author and editor determination regarding acceptance. For each submission, the genders of the first author, last (senior) author and corresponding author were determined because these are authorship positions generally determined by involvement in the work and relevance to academic advancement. Author gender determination was initially made based on personal knowledge of the individual, or by inference using name norms (e.g., Andrew is usually a male name). If author gender was not able to be assigned by this method, an internet search of recognized research websites, professional networking websites and academic institution websites was performed to confirm the gender of each author. Queried websites included researchgate.net, linkedin.com, doximity.com, health.usnews.com, scholar. google.com and healthgrades.com. Authors whose gender was not able to be assigned were excluded from the analysis. For submissions with only a single author, that author was considered a first author and no last author was recorded.

\section{Statistical analysis}

Counts and percentages were used to describe the overall and per-annum distribution of authorship. Chi-square or Fisher exact tests were used to compare authorship gender proportions between periods of interest. To define the effect of the COVID-19 pandemic on authorship, we compared data from 2019 and 2020 on a quarterly basis with specific attention to the time of mandated social distancing in 2020.

\section{Results}

\section{Manuscript submissions}

The total number of submissions from North America during the study period was 1,018 with 257 manuscripts submitted in 2017, 236 in 2018, 238 in 2019 and 287 in 2020. One 
Table 1 Authorship gender by submitted manuscript type

\begin{tabular}{|c|c|c|c|c|c|c|}
\hline \multirow[t]{2}{*}{ Manuscript type } & \multicolumn{2}{|c|}{ First author } & \multicolumn{2}{|c|}{ Last author } & \multicolumn{2}{|c|}{ Corresponding author } \\
\hline & $\begin{array}{l}\text { Male } \\
(\%)\end{array}$ & $\begin{array}{l}\text { Female } \\
(\%)\end{array}$ & $\begin{array}{l}\text { Male } \\
(\%)\end{array}$ & $\begin{array}{l}\text { Female } \\
(\%)\end{array}$ & $\begin{array}{l}\text { Male } \\
(\%)\end{array}$ & $\begin{array}{l}\text { Female } \\
(\%)\end{array}$ \\
\hline Original article & $\begin{array}{l}348 / 594 \\
(58.6)\end{array}$ & $\begin{array}{l}246 / 594 \\
(41.4)\end{array}$ & $\begin{array}{l}359 / 596 \\
(60.2)\end{array}$ & $\begin{array}{l}237 / 596 \\
(39.8)\end{array}$ & $\begin{array}{l}388 / 594 \\
(65.3)\end{array}$ & $\begin{array}{l}206 / 594 \\
(34.7)\end{array}$ \\
\hline Case report & $\begin{array}{l}126 / 204 \\
(61.8)\end{array}$ & $\begin{array}{l}78 / 204 \\
(38.2)\end{array}$ & $\begin{array}{l}134 / 207 \\
(64.7)\end{array}$ & $\begin{array}{l}73 / 207 \\
(35.3)\end{array}$ & $\begin{array}{l}132 / 204 \\
(64.7)\end{array}$ & $\begin{array}{l}72 / 204 \\
(35.3)\end{array}$ \\
\hline Review & $\begin{array}{l}44 / 83 \\
(53.0)\end{array}$ & $\begin{array}{l}39 / 83 \\
(47.0)\end{array}$ & $\begin{array}{l}47 / 83 \\
(56.6)\end{array}$ & $\begin{array}{l}36 / 83 \\
(43.4)\end{array}$ & $\begin{array}{l}49 / 78 \\
(62.8)\end{array}$ & $\begin{array}{l}29 / 78 \\
(37.2)\end{array}$ \\
\hline Pictorial essay & $\begin{array}{l}33 / 69 \\
(47.9)\end{array}$ & $\begin{array}{l}36 / 69 \\
(52.2)\end{array}$ & $\begin{array}{l}30 / 68 \\
(44.1)\end{array}$ & $\begin{array}{l}38 / 68 \\
(55.9)\end{array}$ & $\begin{array}{l}33 / 65 \\
(50.8)\end{array}$ & $\begin{array}{l}32 / 65 \\
(49.2)\end{array}$ \\
\hline Technical innovation & $\begin{array}{l}27 / 36 \\
(75.0)\end{array}$ & $\begin{array}{l}9 / 36 \\
(25.0)\end{array}$ & $\begin{array}{l}38 / 36 \\
(77.8)\end{array}$ & $\begin{array}{l}8 / 36 \\
(22.2)\end{array}$ & $\begin{array}{l}30 / 37 \\
(81.1)\end{array}$ & $\begin{array}{l}7 / 37 \\
(18.9)\end{array}$ \\
\hline How I do it & $\begin{array}{l}1 / 2 \\
(50.0)\end{array}$ & $\begin{array}{l}1 / 2 \\
(50.0)\end{array}$ & $\begin{array}{l}1 / 2 \\
(50.0)\end{array}$ & $\begin{array}{l}1 / 2 \\
(50.0)\end{array}$ & $\begin{array}{l}1 / 2 \\
(50.0)\end{array}$ & $\begin{array}{l}1 / 2 \\
(50.0)\end{array}$ \\
\hline Research forum & $\begin{array}{l}1 / 1 \\
(100)\end{array}$ & $\begin{array}{l}0 / 1 \\
(0)\end{array}$ & $\begin{array}{l}1 / 1 \\
(100)\end{array}$ & $\begin{array}{l}0 / 1 \\
(0)\end{array}$ & $\begin{array}{l}1 / 1 \\
(100)\end{array}$ & $\begin{array}{l}0 / 1 \\
(0)\end{array}$ \\
\hline
\end{tabular}

Denominators differ based on the number of authors per submission hundred and eighteen (11.8\%) manuscripts were submitted by corresponding authors from Canadian institutions, 880 $(87.9 \%)$ were submitted by corresponding authors from institutions in the United States and 3 manuscripts were submitted by corresponding authors from institutions in Mexico.

Twenty manuscripts ( $2 \%$ of 1,018$)$ had a single author. Twelve first author genders, four last author genders and six corresponding author genders (five of which were unidentified first authors) could not be inferred or confirmed. One first author was identified to be transgender. Authorship gender frequency based on submitted manuscript type is detailed in Table 1. Only for pictorial essays did women outnumber men in absolute terms as first authors and last authors. Women did not outnumber men as corresponding authors for any manuscript type. When considering educational manuscripts (reviews and pictorial essays) versus other manuscript types, women were statistically significantly more represented as first authors (49\% [75/152] vs. 40\% [334/837], $P=0.032$ ) and last authors $(49.1 \%$ [74/151] vs. 37.9\% [319/842], $P=0.011)$. For corresponding authorship of educational manuscripts, there was a similar trend that did not meet statistical significance $(42.6 \%$ [61/143] vs. $34.1 \%$ [286/838], $P=0.058)$.

The frequency of female first, last and corresponding authorship is detailed in Table 2 . There was no statistically significant difference in the frequency of female authorship over time $(P=0.46, P=0.19$ and $P=0.97$ for first, last and corresponding author, respectively). However, there is a trend of increasing female first authorship over the study period, with the absolute percentage of submissions by women as first authors increasing from $38.6 \%$ in 2017 to $43.2 \%$ in 2020 .
Table 2 Authorship gender details for submitted manuscripts by year

\begin{tabular}{|c|c|c|c|c|c|c|}
\hline \multirow[t]{2}{*}{ Year } & \multicolumn{2}{|c|}{ First author } & \multicolumn{2}{|c|}{ Last author } & \multicolumn{2}{|c|}{ Corresponding author } \\
\hline & $\begin{array}{l}\text { Male } \\
(\%)\end{array}$ & $\begin{array}{l}\text { Female } \\
(\%)\end{array}$ & $\begin{array}{l}\text { Male } \\
(\%)\end{array}$ & $\begin{array}{l}\text { Female } \\
(\%)\end{array}$ & $\begin{array}{l}\text { Male } \\
(\%)\end{array}$ & $\begin{array}{l}\text { Female } \\
(\%)\end{array}$ \\
\hline 2017 & $\begin{array}{l}151 / 246 \\
(61.3)\end{array}$ & $\begin{array}{l}95 / 246 \\
(38.6)\end{array}$ & $\begin{array}{l}152 / 245 \\
(62.0)\end{array}$ & $\begin{array}{l}93 / 245 \\
(38.0)\end{array}$ & $\begin{array}{l}150 / 245 \\
(61.2)\end{array}$ & $\begin{array}{l}95 / 245 \\
(38.8)\end{array}$ \\
\hline 2018 & $\begin{array}{l}141 / 231 \\
(61.0)\end{array}$ & $\begin{array}{l}90 / 231 \\
(39.0)\end{array}$ & $\begin{array}{l}158 / 228 \\
(69.3)\end{array}$ & $\begin{array}{l}70 / 228 \\
(30.7)\end{array}$ & $\begin{array}{l}141 / 233 \\
(60.5)\end{array}$ & $\begin{array}{l}92 / 233 \\
(39.5)\end{array}$ \\
\hline 2019 & $\begin{array}{l}129 / 232 \\
(55.6)\end{array}$ & $\begin{array}{l}103 / 232 \\
(44.4)\end{array}$ & $\begin{array}{l}141 / 232 \\
(60.8)\end{array}$ & $\begin{array}{l}91 / 232 \\
(39.2)\end{array}$ & $\begin{array}{l}142 / 233 \\
(60.9)\end{array}$ & $\begin{array}{l}91 / 233 \\
(39.1)\end{array}$ \\
\hline 2020 & $\begin{array}{l}159 / 280 \\
(56.7)\end{array}$ & $\begin{array}{l}121 / 280 \\
(43.3)\end{array}$ & $\begin{array}{l}183 / 276 \\
(66.3)\end{array}$ & $\begin{array}{l}93 / 276 \\
(33.7)\end{array}$ & $\begin{array}{l}167 / 282 \\
(59.2)\end{array}$ & $\begin{array}{l}115 / 282 \\
(40.8)\end{array}$ \\
\hline Overall & $\begin{array}{l}580 / 989 \\
(58.6)\end{array}$ & $\begin{array}{l}409 / 989 \\
(41.4)\end{array}$ & $\begin{array}{l}\text { 634/981 } \\
(64.6)\end{array}$ & $\begin{array}{l}347 / 981 \\
(35.4)\end{array}$ & $\begin{array}{l}600 / 993 \\
(60.4)\end{array}$ & $\begin{array}{l}393 / 993 \\
(39.6)\end{array}$ \\
\hline
\end{tabular}

Denominators differ based on the number of authors per submission 
Table 3 Manuscript submissions by quarter in 2019 and 2020

\begin{tabular}{lllll}
\hline Quarter & $\begin{array}{l}\text { Total submis- } \\
\text { sions }\end{array}$ & $\begin{array}{l}\text { Female first author } \\
\text { submissions } \\
(\%)\end{array}$ & $\begin{array}{l}\text { Female last author } \\
\text { submissions } \\
(\%)\end{array}$ & $\begin{array}{l}\text { Female correspond- } \\
\text { ing author submis- } \\
\text { sions } \\
(\%)\end{array}$ \\
\hline Q1 2019 & 60 & $25(41.7)$ & $17(29.3)$ & $23(38.3)$ \\
Q2 2019 & 57 & $27(47.4)$ & $28(50.0)$ & $24(42.1)$ \\
Q3 2019 & 56 & $29(51.8)$ & $23(39.0)$ & $24(41.4)$ \\
Q4 2019 & 59 & $22(37.3)$ & $23(39.0)$ & $20(34.5)$ \\
Q1 2020 & 49 & $18(36.7)$ & $15(30.6)$ & $21(42.9)$ \\
Q2 2020 & 105 & $51(48.5)$ & $31(30.3)$ & $41(39.0)$ \\
Q3 2020 & 67 & $23(34.3)$ & $19(28.8)$ & $24(34.8)$ \\
Q4 2020 & 59 & $29(49.2)$ & $28(47.5)$ & $29(49.2)$ \\
\hline
\end{tabular}

Q1 January-March, $Q 2$ April-June, $Q 3$ July-September, $Q 4$ October-December

\section{9 versus 2020 comparison}

Focusing on 2020 versus the immediately preceding year, analysis of submissions by quarter (Table 3) showed an increase in submissions in the second quarter of 2020. The proportion of women as first and corresponding authors was similar between 2019 and 2020 for all quarters, with no statistically significant differences $(P>0.05)$. The proportion of female last authors was statistically significantly lower in the second quarter of 2020 compared to 2019 (30\% vs. 50\%, $P=0.017)$ but was similar in all other quarters $(P>0.05)$.

\section{Manuscript disposition}

Overall acceptance frequency of included submitted manuscripts was $44.2 \%$ (414/937). Manuscript disposition by submitting author gender is detailed in Table 4. During the entire study period, the frequency of female first, last and corresponding authorship of accepted manuscripts was $42.8 \%$ (177/414), 34.1\% (141/414) and 40.6\% (168/414), respectively. There was no statistically significant difference in manuscript disposition based on authorship gender ( $P=0.33, P=0.61$ and $P=0.41$ for first, last and corresponding author, respectively).

\section{Discussion}

For the years 2017 to 2020, fewer manuscripts submitted to Pediatric Radiology were authored by women than men and this gender imbalance was similarly reflected in accepted manuscripts. Broadly, women were first, last and corresponding authors on $41 \%, 35 \%$ and $40 \%$ of submitted manuscripts, respectively, and $43 \%, 34 \%$ and $40 \%$ of accepted manuscripts, respectively. While there was no significant difference in the frequency of female authorship from year
Table 4 Frequency of accepted manuscripts by authorship gender

\begin{tabular}{|c|c|c|c|c|c|c|}
\hline \multirow[t]{2}{*}{ Year } & \multicolumn{2}{|c|}{ First author } & \multicolumn{2}{|c|}{ Last author } & \multicolumn{2}{|c|}{ Corresponding author } \\
\hline & $\begin{array}{l}\text { Male } \\
(\%)\end{array}$ & $\begin{array}{l}\text { Female } \\
(\%)\end{array}$ & $\begin{array}{l}\text { Male } \\
(\%)\end{array}$ & $\begin{array}{l}\text { Female } \\
(\%)\end{array}$ & $\begin{array}{l}\text { Male } \\
(\%)\end{array}$ & $\begin{array}{l}\text { Female } \\
(\%)\end{array}$ \\
\hline \multirow[t]{2}{*}{2017} & $65 / 150$ & $33 / 93$ & $64 / 150$ & $35 / 92$ & $64 / 149$ & $34 / 93$ \\
\hline & $(43.3)$ & $(35.5)$ & $(42.7)$ & $(38.0)$ & $(43.0)$ & $(36.6)$ \\
\hline \multirow[t]{2}{*}{2018} & $62 / 140$ & $47 / 90$ & $71 / 157$ & $38 / 70$ & $59 / 140$ & $51 / 92$ \\
\hline & $(44.3)$ & $(52.2)$ & $(45.2)$ & $(54.3)$ & $(42.1)$ & $(55.4)$ \\
\hline \multirow[t]{2}{*}{2019} & $56 / 129$ & $61 / 103$ & $74 / 141$ & $44 / 91$ & $64 / 142$ & $53 / 91$ \\
\hline & $(43.4)$ & $(59.2)$ & $(52.5)$ & $(48.4)$ & $(45.1)$ & $(58.2)$ \\
\hline \multirow[t]{2}{*}{2020} & $54 / 134$ & $36 / 98$ & $64 / 157$ & $24 / 72$ & $60 / 143$ & $30 / 91$ \\
\hline & $(40.3)$ & $(36.8)$ & $(40.8)$ & $(33.3)$ & $(42.0)$ & $(33.0)$ \\
\hline \multirow[t]{2}{*}{ Overall } & $237 / 553$ & $177 / 384$ & $273 / 605$ & $141 / 325$ & $247 / 574$ & $168 / 367$ \\
\hline & $(42.9)$ & $(46.1)$ & $(45.1)$ & $(43.4)$ & $(43.0)$ & $(45.8)$ \\
\hline
\end{tabular}

Denominator reflects number of submissions by authors of that gender. Final manuscript disposition was not available for 3, 1, 0 and 48 manuscripts in 2017, 2018, 2019 and 2020, respectively. This reflects missing data in the journal database 
to year, there is an apparent upward trend in the absolute number of female first authors of submitted manuscripts over time. Female last and corresponding authorship of submitted manuscripts remained relatively stable.

With regard to an overall gender imbalance of authorship, our findings are similar to those reported for other radiology journals. A large study of the top 50 medical imaging journals evaluating authorship of submissions from March to May of $2018(n=2,238), 2019(n=2,355)$ and 2020 $(n=2,480)$ showed female first authorship and last authorship in $2018-2019$ were $31.6 \%$ and $19.3 \%$, respectively, and $32.3 \%$ and $20.7 \%$ in 2020 , respectively [10]. Another recent study evaluating gender differences in the authorship of publications in the Journal of the American College of Radiology during April to October of 2019 versus the same period in 2020 showed female first authorship being $45 \%$ and $39 \%$, respectively, and female corresponding authorship being $42.4 \%$ and $37.4 \%$, respectively [11]. Of note, female last authorship in Pediatric Radiology was higher than the overall frequency in the large-scale study and closer to the frequency of corresponding authorship in the Journal of the American College of Radiology study.

Academic radiologists in the United States are predominantly men. A study of 5,089 academic radiologists in 2014 showed $71.5 \%$ to be men [9]. However, the relative proportion of men and women differs by subspecialty. A 2019 study evaluating academic pediatric radiologists in the United States and Canada found that $46 \%$ were women, suggesting higher proportional representation of women in pediatric radiology relative to other radiology subspecialties [14]. This statistic aligns with the female membership of the SPR. As of May 2021, the membership of the SPR was $42.5 \%$ female $(852 / 2,001)$ and the active membership was $46 \%$ female $(575 / 1,249)$ (correspondence with SPR administration). Given this representation of women in academic pediatric radiology and the SPR, our results suggest that authorship of manuscripts by women submitted to and accepted by Pediatric Radiology is slightly under-representative.

The relative authorship gender distribution for specific manuscript types generally paralleled the overall authorship gender distribution of all submissions to Pediatric Radiology with men outnumbering women. The only manuscript types for which female first and last authors outnumbered male authors were educational manuscripts (reviews and pictorial essays), with a higher proportion of female authors for these submissions than other manuscript types. This finding is supported by a recent study that showed that women in all subspecialties of radiology have a higher representation in authorship of education manuscripts as well as more representation in educational leadership positions [15]. This apparent predilection toward education and production of educational material is important to consider as it relates to the academic advancement of women. There are some institutions where educational roles are not as highly valued as other promotion tracks in the academic hierarchy. Further, it has been shown that women in education roles less frequently rise to major departmental roles, potentially creating an advancement ceiling [16].

\section{Impact of the COVID-19 pandemic}

The COVID-19 pandemic had the potential to exacerbate gender imbalances in manuscript submissions as women are disproportionately more likely to be primary caregivers in a household and much of the new non-work-related responsibilities during this time likely fell upon them [2-4]. During the early phase of the COVID-19 pandemic (second quarter of 2020), there was an increase in overall manuscript submissions to Pediatric Radiology, but the relative proportion of female first authorship did not significantly change. However, there was a statistically significant decrease in the proportion of female last authors compared to the same quarter in 2019. Given that last authorship is often associated with a supervisory role/status for a manuscript, this relative decrease of female representation could reflect decreased availability to supervise research. The second quarter of 2020 encompassed periods of recommended or mandated social distancing, leading to significant changes in daily life, including increased remote working capabilities and disruption to childcare as well as new responsibilities with distance learning for children.

Other studies have seen a more pronounced effect associated with the COVID-19 pandemic, with decreases in female authorship of manuscripts in science and medicine across the board [7, 17, 18]. Similar trends were shown for radiology. One study showed an overall decreased proportion of female first author submissions during the 2020 study period in comparison to the same period in 2019, as well as a statistically significant lower proportion of female first authors for COVID-19 related publications in the Journal of the American College of Radiology [11]. This observation was hypothesized to be potentially disadvantageous to academic advancement for women in radiology, especially those in their early career and more likely to have non-workrelated responsibilities that were heightened during the early phase of the COVID-19 pandemic.

The long-term effects of the COVID-19 pandemic on female academic advancement in pediatric radiology, and how these effects will build on preexisting gender inequities, are yet to be determined. Given the potential detrimental effect of the pandemic described in other studies, it is important to be aware of the unique challenges that women faced during this time and to provide supportive institutional and departmental policies and resources to prevent these impacts from worsening [19]. 


\section{Limitations}

There are several limitations to our study. First, only manuscript submissions from North America were included in the analysis. Because authors do not provide their gender to the journal, we had to infer author gender based on name norms, through web searches and based on inference from physical appearance. Inference of gender based on name norms was not possible for authors from other continents. The result of this is that our study does not represent the totality of submissions to Pediatric Radiology and there may be inaccuracies in gender determination. Further, this accounts for small sample sizes insufficient to achieve statistical power for many of the comparisons. Future studies evaluating gender trends of international authors submitting to Pediatric Radiology, as well as longitudinal information regarding gender differences in authorship, would be informative to better characterize trends in authorship gender and to define the impact of the COVID-19 pandemic both locally and globally on academic pediatric radiology. Second, given the limited sample size in this study, authorship for COVID-19-related manuscripts was not separately analyzed, as has been done in other previous radiology publication authorship studies. Third, at the time of writing this manuscript, the disposition of many of the submitted manuscripts in 2020 was not determined and therefore was not included in the results and analysis. Finally, while we analyzed manuscript submissions on a quarterly basis, the time to perform research and prepare manuscripts is highly variable and may have extended beyond the period during which the manuscript was submitted.

\section{Conclusion}

The proportion of female authors of manuscripts submitted to Pediatric Radiology from North America between 2017 and 2020 has remained relatively stable but slightly underrepresents women in academic pediatric radiology. During the COVID-19 pandemic, the relative frequency of authorship of manuscripts by women did not change significantly except for last authorship during the early phase (March to May 2020) of the pandemic.

Acknowledgments We would like to acknowledge Stephanie Custer for her help in obtaining the records for the data for this paper.

\section{Declarations}

Conflicts of interest None

\section{References}

1. Jolly S, Griffith KA, DeCastro R et al (2014) Gender differences in time spent on parenting and domestic responsibilities by high-achieving young physician-researchers. Ann Intern Med 160:344-353

2. Sepulveda KA, Paladin AM, Rawson JV (2018) Gender diversity in academic radiology departments: barriers and best practices to optimizing inclusion and developing women leaders. Acad Radiol 25:556-560

3. Zamarro G, Prados M (2021) Gender differences in couples' division of childcare, work and mental health during COVID-19. Rev Econ Household 19:11-40

4. Giurge LM, Whillans AV, Yemiscigil A (2021) A multicountry perspective on gender differences in time use during COVID-19. Proc Natl Acad Sci U S A 118:e2018494118

5. UN Women (2018) Turning promises into action: gender equality in the 2030 Agenda for Sustainable Development. https://www.unwomen. org/-/media/headquarters/attachments/sections/library/publications/ 2018/sdg-report-gender-equality-in-the-2030-agenda-for-sustainabledevelopment-2018-en.pdf?la=en\&vs=4332. Accessed 20 Sep 2021

6. Starmer AJ, Frintner MP, Matos K et al (2019) Gender discrepancies related to pediatrician work-life balance and household responsibilities. Pediatrics 144:e20182926

7. Kibbe MR (2020) Consequences of the COVID-19 pandemic on manuscript submissions by women. JAMA Surg 155:803-804

8. Williams WA 2nd, Li A, Goodman DM, Ross LF (2021) Impact of the coronavirus disease 2019 pandemic on authorship gender in the Journal of Pediatrics: disproportionate productivity by international male researchers. J Pediatrics 231:50-54

9. Kapoor N, Blumenthal DM, Smith SE et al (2017) Gender differences in academic rank of radiologists in U.S. medical schools. Radiology 283:140-147

10. Quak E, Girault G, Thenint MA et al (2021) Author gender inequality in medical imaging journals and the COVID-19 pandemic. Radiology 300:E301-E307

11. Mogensen MA, Lee CI, Carlos RC (2021) The impact of the COVID19 pandemic on journal scholarly activity among female contributors. J Am Coll Radiol 18:1044-1047

12. Bender CE, Bansal S, Wolfman D, Parikh JR (2019) 2018 ACR Commission on Human Resources workforce survey. J Am Coll Radiol 16:508-512

13. Pfeifer CM, Gokli A, Reid JR (2020) Advancing from gender equity to women in leadership in pediatric radiology. Pediatr Radiol 50:631-633

14. Counter WB, Khurshid K, Jalal S et al (2020) Gender differences among academic pediatric radiology faculty in the United States and Canada. Acad Radiol 27:575-581

15. Webb EM, Kallianos KG, Vella M et al (2020) Are women disproportionately represented in education compared to other roles in academic radiology? Acad Radiol 27:1767-1773

16. Mayer AP, Blair JE, Ko MG et al (2014) Gender distribution of U.S. medical school faculty by academic track type. Acad Med 89:312-317

17. Muric G, Lerman K, Ferrara E (2020) Gender disparity in the authorship of biomedical research publications during the COVID-19 pandemic. J Med Internet Res 23:e25379

18. Bell ML, Fong KC (2021) Gender differences in first and corresponding authorship in public health research submissions during the COVID-19 pandemic. Am J Public Health 111:159-163

19. Narayana S, Roy B, Merriam S et al (2020) Minding the gap: organizational strategies to promote gender equity in academic medicine during the COVID-19 pandemic. J GenIntern Med 35:3681-3684

Publisher's note Springer Nature remains neutral with regard to jurisdictional claims in published maps and institutional affiliations. 